\title{
STRATEGI PEMBELAJARAN BERBASIS MASALAH DAN GAYA BERPIKIR TERHADAP HASIL BELAJAR SISWA PADA PELAJARAN ILMU PENGETAHUAN SOSIAL (IPS)
}

\author{
Iin Mirna Fathima'), R. Andi Ahmad Gunadi' ${ }^{2}$, Dirgantara Wicaksono ${ }^{3)}$ \\ ${ }^{1}$ Sekolah Budi Mulia Dua Bintaro \\ email: iinmirna@gmail.com \\ ${ }^{2}$ Magister Teknologi Pendidikan, Universitas Muhammadiyah Jakarta \\ email: aagunadi@umj.ac.id \\ ${ }^{3}$ Magister Teknologi Pendidikan, Universitas Muhammadiyah Jakarta \\ email: dirgantarawicaksono@umj.ac.id
}

\begin{abstract}
The purpose of this study was to determine the effect of learning outcomes on problem-based learning strategies by focused to student learning styles. In learningprocess, elementary school especially for social studies, have several problems, there are differences in student learning outcomes by using problem-based and cooperative learning strategies, are there any interactions between learning strategies and thinking styles (divergent and convergent) on student learning outcomes, are there differences learning outcomes in problem-based learning strategies and students 'thinking styles towards social studies learning outcomes, and whether differences in learning outcomes in cooperative learning strategies and students' thinking styles towards social studies learning outcomes. This research was conducted at Budi Mulia Dua Bintaro Elementary School. It used is quantitative research method with data analysis using factorial experiment design. There are the differences in social studies which learning outcomes by problem-based learning strategy has an average of 22.143 higher than using cooperative learning strategies who have divergent thinking styles has average of 16.00. Social studies subjects are more suitable to use problem-based learning strategies, problem-based learning strategies are more suitable for students who have divergent thinking styles, cooperative learning strategies are more suitable for students who have convergent thinking styles, there are interactions between learning strategies and thinking styles with learning outcomes with paying attention to students' thinking styles can optimize social studies learning outcomes.
\end{abstract}

Keywords: problem-based learning strategies, thinking styles

\section{Abstrak}

Penelitian ini bertujuan untuk menguji secara empiris dan meneliti pengaruh strategi pembelajaran berbasis masalah dan gaya berpikir terhadap hasil belajar pada mata pelajaran IPS. Tujuan penelitian ini adalah untuk mengetahui pengaruh strategi pembelajaran dan gaya berpikir terhadap hasil belajar. Penelitian ini dilaksanakan di SDS Budi Mulia Dua Bintaro. Metode yang digunakan adalah metode survey dengan manggunakan angket dan dokumentasi. Sampel yang digunakan dalam penelitian ini adalah kelas IV yang berjumlah 50 anak. Instrumen sebanyak 20 pernyataan untuk strategi pembelajaran dan 10 soal untuk gaya berpikir anak. Analisis data menggunakan uji korelasi koefisien yang terdapat adanya pengaruh strategi pembelajaran berbasis masalah dengan gaya berpikir siswa terhadap hasil belajar IPS. Hasil penelitian ini diharapkan dapat bermanfaat kepada pihak-pihak terkait yang dapat memanfaatkan seperti kepala sekolah, guru, siswa, dan peneliti selanjutnya.

Kata kunci: strategi pembelajaran, gaya berpikir, hasil belajar IPS

\section{PENDAHULUAN}

Kemajuan peradaban di sebuah negara merupakan salah satu indikator dari kemajuan sistem pendidikan di negara tersebut. Pendidikan merupakan usaha secara sadar dalam mentransfer ilmu pengetahuan.
Sehingga negara yang memiliki kualitas pendidikan yang baik, akan tercermin dalam kualitas penduduknya.

Hasil studi TIMSS tahun 2015 (Trends in International Mathematics and Science Study) menunjukkan siswa Indonesia berada 
pada ranking amat rendah dalam kemampuan (1) memahami informasi yang komplek, (2) teori, analisis, dan pemecahan masalah, (3) pemakaian alat, prosedur dan pemecahan masalah, dan (4) melakukan investigasi. Hal ini menunjukkan bahwa siswa Indonesia belum mampu menyelesaikan soal-soal yang menuntut kemampuan berpikir secara divergen dan kreatif menganalisa soal dan menentukan jawaban atas persoalan tersebut.

Salah satu penyebab dari kurangnya kemampuan berpikir secara kreatif karena dalam proses pembelajaran IPS pemilihan strategi pembelajaran yang kurang sesuai dalam memahami konsep pembelajaran IPS. Ketidak mampuan siswa dalam hal ini mengakibatkan siswa tidak mampu menyelesaikan permasalahan-permasalahan yang ada dalam pelajaran IPS. Pada proses pembelajaran, masih banyak guru yang tidak memperhatikan gaya berpikir siswa, sehingga pembelajaran tidak optimal dikarenakan kondisi yang tidak sesuai dengan gaya berpikir siswa.

Melalui strategi pembelajaran berbasis masalah, ada bagian yang menarik untuk dijadikan penelitian dimana siswa diharapkan bisa melakukan identifikasi dari kebudayaan Hindu/Budha/Islam dan pengaruhnya pada masa kini dimana topik pembelajaran pada bagaimana siswa mengembangkan pemikiran mengenai sikap kepahalawanan dan implementasinya di kehidupan sehari-hari untuk kemudian dilakukan pengembangan solusi melalui identifikasi alternatif-alternatif melalui strategi pembelajaran berbasis masalah.

Terkait permasalahan tersebut, maka peneliti bermaksud melakukan penelitian mengenai pengaruh strategi pembelajaran berbasis masalah dan gaya berpikir terhadap hasil belajar siswa pada pelajaran IPS.

\section{KAJIAN LITERATUR}

Belajar merupakan sebuah proses yang mampu memberikan pengalaman nyata dan melibatkan perubahan tingkah laku pada peserta didik sehingga mereka dapat bekerja sama, berinisiatif, menyelesaikan masalah, mengambil keputusan dan memperoleh ketrampilan. Menurut Gagne "Learning is a process that leads to a change in a learner's disposition and capabilities that can be reflected in behavior." Menurutnya, belajar adalah sebuah proses yang mengarah pada sebuah perubahan dalan disposisi peserta didik dan kapabilitasnya sehingga berpengaruh pada perilaku peserta didik (Gagne, 2005:3). Dengan kata lain Gagne berpendapat bahwa proses belajar terjadi apabila peserta didik mengalami perubahan perilaku yang lebih baik setelah ia mengalami proses belajar tersebut.

Proses belajar dikaitkan dengan faktor kognitif seperti motivasi, minat dan kemampuan siswa untuk melakukan usaha untuk mencapai hasil yang diinginkan. Hasil belajar (behavioral objectives) adalah pernyataan tentang kemampuan atau konsep yang diharapkan akan diketahui siswa pada akhir jangka waktu pembelajaran (Slavin, 2011:255). Hasil belajar adalah kemampuan (kapabilitas belajar) yang diperoleh siswa setelah melakukan proses belajar, sementara untuk merepresentasikan hasil belajar harus memenuhi lima kapabilitas belajar yaitu, Gagne $(1977: 28)$ :

1. Keterampilan intelektual (intellectual skills)

2. Strategi-strategi Kognitif (cognitive strategies)

3. Informasi verbal (verbal information)

4. Keterampilan motor (motor skills)

5. Sikap (attitudes).

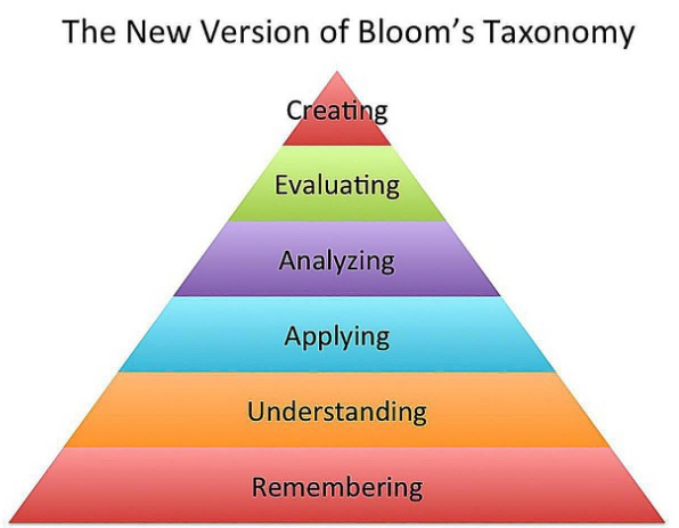

Adapun penjelasan perubahan taksonomi Bloom (Anderson dan Krathwohl 2001:66) adalah sebagai berikut:

a. Mengingat (remember) yaitu mendapatkan kembali pengetahuan yang berhubungan dengan ingatan jangka panjang meliputi 
mengenali (recognize) dan mengingat kembali (recall). Pengetahuan yang relevan bisa dalam bentuk factual, konseptual, prosedural maupun metakognitif;

b. Mengerti (understand) yaitu membangun pemahaman dari pesan-pesan pembelajaran secara lisan, tulisan, dan gambar melalui interpretasi (interprete),mencontohkan (exemply), megklasifikasi (classify), menyimpulkan (inferre), meringkas (summarize), membandingkan (compare) dan menjelaskan (explain). Pengetahuan yang mendukung terbangunnya sebuah pemahaman melalui pengetahuan konseptual;

c. Mengaplikasi (apply) yaitu menggunakan prosedur untuk menyelesaikan atau memecahkan masalah. Membangun pengetahuan dalam mengaplikasi pengetahuan adalah melalui dimensi prosedural. Kategori mengaplikasi meliputi kegiatan membuat (execute) dan mengimplementasikan (implement);

d. Menganalisa (analyze) yaitu melakukan pengklasifikasian ke dalam bagian-bagian pokok dan menentukan bagaimana bagianbagian tersebut berhubungan satu sama lain terhadap keseluruhan struktur serta kemampuan untuk menentukan bagian mana yang relevan dan bagian mana yang penting, yang meliputi kategori membedakan (differentiate), mengorganisasikan (organize), dan menghubungkan (attribute);

e. Mengevaluasi (evaluate) yakni membuat penilaian berdasarkan kriteria dan standar yang ditetapkan. kriteria biasanya menggunakan kualitas, efektifitas, efisiensi dan konsistensi. Sedangkan standar biasanya dalam bentuk kuantitatif ataupun kualitatif. Proses kognitif yang menggunakan kategori mengevaluasi meliputi memeriksa (checked) dan mengkritisi (critique);

f. Mengkreasikan (create) meletakkan elemen-elemen secara bersama untuk membentuk satu kesatuan yang koheren ataupun fungsional. Siswa membuat produk yang secara mental terorganisasi kembali menjadi beberapa elemen ataupun bagian ke dalam sebuah pola-pola struktur baru yang belum ada sebelumnya. Kategori ini meliputi mengeneraqlisasika (generate), merencanakan (plan) dan memproduksi (produce).

Faktor-faktor yang mempengaruhi hasil belajar dibedakan atas 2 (dua) kategori yaitu faktor eksternal yang teridiri dari lingkungan sosial dan lingkungan non social, dan faktor internal yang terdiri dari fisiologis (yang berhubungan dengan kondisi fisik individu) dan faktor psikologis (karakteristik siswa, kecerdasan siswa, motivasi, minat dan bakat siswa). Kedua faktor tersebut saling mempengaruhi dalam proses belajar individu sehingga menentukan kualitas hasil belajar.

Somantri mengidentifikasi sejumlah karakterisktik dari ilmu-ilmu sosial yaitu sebagai berikut:

1) Berbagai batang tubuh pengetahuan (body of knowledge) dari disiplin ilmu-ilmu sosial yang diorganisasikan secara sistematis dan ilmiah.

2) Batang tubuh disiplin itu berrisikan sejumlah teori dan generalisasi yang handal dan kuat serta dapat diuji tingkat kebenarannya.

3) Batang tubuh disiplin ilmi-ilmu sosial ini disebut juga struktur disiplin ilmu, atau ada juga yang menyebutnta dengan fundamental ideas.

4) Teori dan generalisasi dalam struktur itu disebut pula pengetahuan ilmiahnyang dicapai lewat pendekatan konseptual dan syntactic, yaitu lewat proses bertanya, berhipotesis, pengumpulan data (observasi dan eksperimen). (Somantri, 2001)

Berdasarkan identifikasi karakteristik di atas maka dapat disimpulkan bahwa pelajaran IPS adalah cabang dari cabang dari ilmu humaniora yang mempelajari kehidupan manusia dalam sebuah masyarakat yang berkembang dan mengalami perubahan sehingga mempengaruhi kehidupan secara individu maupun dalam kehidupan bermasyarakat.

Menurut Permendiknas No 22 tahun 2006 tentang Standar Isi untuk satuan Pendidikan 
Dasar dan Menengah bahwa mata pelajaran IPS bertujuan agar siswa memiliki kemampuan untuk:

1) Mengenal konsep-konsep yang berkaitan dengan kehidupan masyarakat dan lingkungannya.

2) Memiliki kemampuan dasar untuk berpikir logis dan kritis, rasa ingin tahu, inkuiri, memecahkan masalah, dan keterampilan dalam kehidupan sosial.

3) Memiliki komitmen dan kesadaran terhadap nilai-nilai sosial dan kemanusiaan.

4) Memiliki kemampuan berkomunikasi, bekerjasama dan berkompetisi dalam masyarakat yang majemuk, di tingkat lokal, nasional, dan global.

Tujuan pengajaran pendidikan IPS mencakup tiga aspek yaitu aspek kognitif, afektif, dan psikomotorik. Guru tidak hanya menekankan pada aspek kognitif saja tetapi aspek-aspek yang lain seperti aspek afektif dan psikomotorik.

Strategi pembelajaran yang cocok untuk pembelajaran IPS yaitu salah satunya adalah pembelajaran berbasis masalah, dimana siswa memiliki gaya berpikir yang kreatif sehingga memiliki potensi untuk mengembangkan kemandirian siswa dalam memecahkan masalah yang bermakna bagi kehidupan siswa. Proses berpikir yang dikembangkan dengan menerapkan strategi pembelajaran berbasis masalah menurut Sani adalah:

a) Berpikir membuat perencanaan.

b) Berpikir generatif.

c) Berpikir sistematis.

d) Berpikir analogis.

e) Berpikir sistemik. (Sani, 2014:127)

Pembelajaran dengan menggunakan strategi pembelajaran berbasis masalah memungkinkan siswa untuk terlibat dalam permasalahan dunia nyata, mengembangkan gaya berpikir, keterampilan menyelesaikan masalah serta mampu berkolaborasi dalam menemukan pengetahuan dan pengalaman baru.

\section{METODE PENELITIAN}

Penelitian dilakukan di sekolah dasar swasta, SDS Budi Mulia Dua Bintaro yang bertempat di Jalan Jombang Raya No.89 Kecamatan Ciputat Kota Tangerang Selatan Propinsi Banten, sejak bulan OktoberDesember 2018.

Berdasarkan tujuan penelitian, yaitu untuk menguji pengaruh Strategi Pembelajaran Berbasis Masalah dan Strategi Pembelajaran Kooperatif terhadap hasil belajar IPS siswa kelas 4 SD Budi Mulia Dua Bintaro, maka metode yang digunakan dalam penelitian ini adalah metode penelitian eksperimen.

Oleh karena variabel perlakuan dan variabel moderator masing-masing terbagi dua, maka rancangan penelitian yang tepat digunakan dalam penelitian ini adalah rancangan faktorial $2 \times 2$. Desain eksperimen penelitian disajikan dalam table 3.1, berikut:

\begin{tabular}{|c|c|c|}
\hline \multirow{2}{*}{$\begin{array}{c}\text { GAYA BERPIKIR } \\
(\mathrm{B})\end{array}$} & \multicolumn{2}{|c|}{ STRATEGI PEMBELAJARAN } \\
\cline { 2 - 3 } & $\begin{array}{c}\mathrm{PBL} \\
(\mathrm{A} 1)\end{array}$ & $\begin{array}{c}\text { Kooperatif } \\
\text { (A2) }\end{array}$ \\
\hline $\begin{array}{c}\text { DIVERGEN } \\
\text { (B1) }\end{array}$ & $\mathrm{A}_{1} \mathrm{~B}_{1}$ & $\mathrm{~A}_{2} \mathrm{~B}_{1}$ \\
\hline $\begin{array}{c}\text { KONVERGEN } \\
\text { (B2) }\end{array}$ & $\mathrm{A}_{1} \mathrm{~B}_{2}$ & $\mathrm{~A}_{2} \mathrm{~B}_{2}$ \\
\hline
\end{tabular}

Keterangan :

A1 B1: hasil belajar IPS dengan strategi pembelajaran berbasis masalah dengan gaya berpikir divergen.

A1 B2: hasil belajar IPS dengan strategi pembelajaran berbasis masalah dengan gaya berpikir konvergen.

A2 B1: hasil belajar IPS dengan strategi pembelajaran dengan kooperatif dengan gaya berpikir divergen.

A2 B2: hasil belajar IPS dengan strategi pembelajaran dengan kooperatif dengan gaya berpikir konvergen.

Teknik pengambilan sampel yang digunakan dalam penelitian ini menggunakan purposive random sampling. Sehingga terpilihlH Populasi target atau sampling frame dalam penelitian ini adalah seluruh siswa SDS Budi Mulia Dua Bintaro tahun ajaran 2018/2019. 
Berdasarkan teknik purposive random sampling, peneliti menentukan kriteria yaitu

\begin{tabular}{|c|c|c|c|c|c|c|}
\hline \multirow[t]{2}{*}{ Variabel } & \multirow[t]{2}{*}{$\begin{array}{c}\text { Kompetensi } \\
\text { Dasar }\end{array}$} & \multirow[t]{2}{*}{ Indikator } & \multicolumn{3}{|c|}{$\begin{array}{c}\text { Taksonomi } \\
\text { Bloom }\end{array}$} & \multirow{2}{*}{$\begin{array}{c}\text { Juml } \\
\text { ah } \\
\text { soal }\end{array}$} \\
\hline & & & C4 & $\mathrm{C5}$ & C6 & \\
\hline \multirow[t]{5}{*}{$\begin{array}{l}\text { Hasil } \\
\text { Belajar }\end{array}$} & \multirow{5}{*}{$\begin{array}{l}\text { mengidentifika } \\
\text { sikan kerajaan } \\
\text { Hindu } \\
\text { dan/atau } \\
\text { Budha } \\
\text { dan/atau Islam } \\
\text { di lingkungan } \\
\text { setempat, } \\
\text { serta } \\
\text { pengaruhnya } \\
\text { pada } \\
\text { kehidupan } \\
\text { masyarakat } \\
\text { masa kini. }\end{array}$} & $\begin{array}{l}\text { Menganalisa } \\
\text { karakterisktik } \\
\text { sebagai } \\
\text { pahlawan }\end{array}$ & $\checkmark$ & & & 3 \\
\hline & & $\begin{array}{l}\text { Mengevaluasi } \\
\text { sikap } \\
\text { kepahlawanan } \\
\text { yang benar }\end{array}$ & & $\checkmark$ & & 5 \\
\hline & & $\begin{array}{l}\text { Mencari } \\
\text { informasi } \\
\text { mengenai sosok } \\
\text { pahlawan }\end{array}$ & $\checkmark$ & & & 5 \\
\hline & & $\begin{array}{l}\text { Menganalisa } \\
\text { sikap } \\
\text { kepahlawanan } \\
\text { dari pahlawan } \\
\text { nasional }\end{array}$ & $\checkmark$ & & & 8 \\
\hline & & $\begin{array}{l}\text { Mengkomunika } \\
\text { sikan sikap } \\
\text { kepahlawanan }\end{array}$ & & & $\checkmark$ & 4 \\
\hline
\end{tabular}

siswa yang sudah bisa mengembangkan gaya berpikir yaitu siswa SD kelas atas atau kelas 4-6 SD, dalam hal ini peneliti memilih siswa kelas 4 SD. Kriteria berikutnya adalah siswa yang sudah mampu melakukan kegiatan pembelajaran dengan berbagai strategi pembelajaran khususnya pembelajaran dalam kelompok. Populasi terjangkau dalam penelitian ini yaitu teridiri dari 3 kelas, 25 siswa kelas 4 Sympathy, 25 siswa dari kelas 4 Responsible dan 25 kelas 4 Careful SD Budi Mulia Dua Bintaro. Pengambilan populasi terjangkau ini karena berkaitan dengan pelajaran IPS.

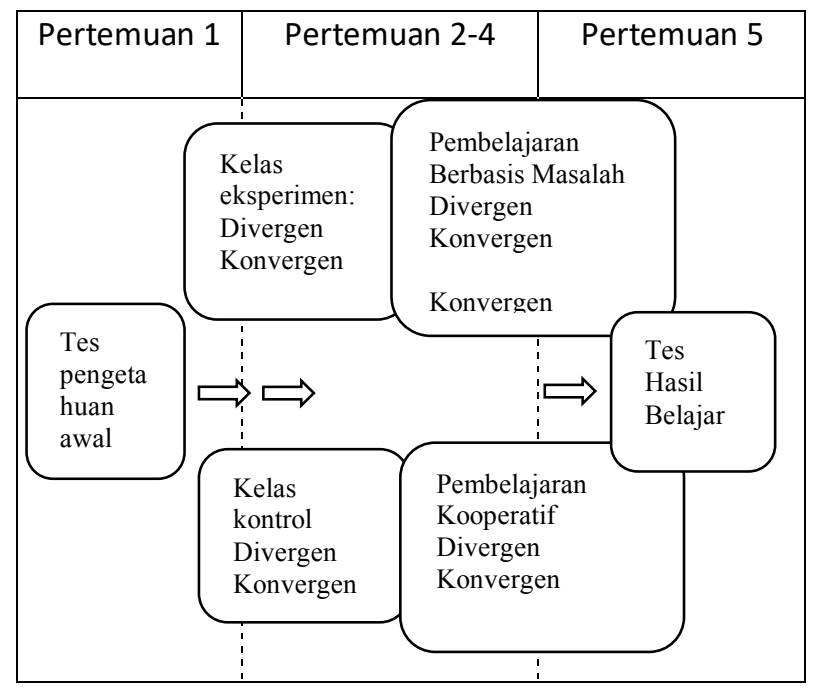

\begin{tabular}{|c|c|c|}
\hline Tes & Perlakuan & Post Test \\
Pengetahuan & & \\
Awal & & \\
\hline
\end{tabular}

Pengumpulan data dalam penelitian ini menggunakan instrumen penelitian berupa instrumen tes hasil belajar, instrumen gaya berpikir, dan instrumen tes pengetahuan awal. Instrumen tes hasil belajar digunakan untuk mengukur sejauh mana siswa menguasai materi IPS, instrumen gaya berpikir digunakan untuk membdakan kecenderunagn gaya berpikir diveren dan konergen siswa, dan instrummen tes kemampuan awal digunakan untuk mengukur tingkat penguasaan materi pembelajaran yang harus dimiliki sebelum siswa mengikuti mata pelajaran IPS.

Keterangan

C4: Menganalisis yakni dengan mengelompokkan data, menganalisis proes dan merumuskan masalah.

C5: Mengevaluasi yakni dengan membuat kesimpulan, merancang pecobaan dan membuat perbandingan.

C6: Mencipta yakni dengan merumuskan langkah pemecahan masalah dan menghubungkan data.

$$
\mathrm{NP}=\frac{\mathrm{R}}{\mathrm{SM}} \times 100
$$

\section{Keterangan}

NP : Nilai persen yang dicari atau diharapkan

$\mathrm{R} \quad$ : Skor mentah yang diperoleh siswa SM : Skor maksimum ideal dari tes yang bersangkutan

100 : Bilangan tetap

Untuk menghitung koefisien korelasinya digunakan rumus Point Biserial Correlattion

$$
r_{p b i s}=\frac{M p-M t}{S t} \sqrt{\frac{p}{q}}
$$

Keterangan

$\mathrm{r}_{\mathrm{pbis}} \quad$ : koefisien korelasi point biserial 
$\mathrm{M}_{\mathrm{p}} \quad$ : mean skor dari subjek yang menjawab benar item yang dikorelasi

$\mathrm{M}_{\mathrm{t}} \quad$ : mean skor total

$\mathrm{S}_{\mathrm{t}} \quad$ : simpangan baku

$\mathrm{P} \quad$ : proporsi subjek yang menjawab benar item tersebut

$\mathrm{q} \quad: 1-\mathrm{P}$

Bentuk instrumen gaya berpikir membutuhkan respon politomi, maka validitas butir menurut Sugiyono (2012:356) dapat dihitung menggunakan rumus Product Moment Correlation.

$$
r_{x y}=\frac{\sum x y}{\sqrt{\left(\sum x^{2}\right)\left(\sum y^{2}\right)}}
$$

Keterangan

$\mathrm{r}_{\mathrm{xy}} \quad$ : koefisien korelasi antara variabel $\mathrm{x}$ dan variabel $\mathrm{y}$, dua variabel yang dikorelasikan $\left(\mathrm{x}=\mathrm{X}-\mathrm{X}_{\text {rerata }}\right.$ dan $\mathrm{y}=\mathrm{Y}$ $Y_{\text {rerata) }}$

¿xy : jumlah perkalian $\mathrm{x}$ dan $\mathrm{y}$

$\mathrm{X}^{2} \quad$ : kuadrat dari $\mathrm{x}$

$\mathrm{Y}^{2} \quad$ : kuadrat dari $\mathrm{y}$

Instrumen gaya berpikir dalam penelitian ini datanya adalah data politomi, maka perhitungan koefisien realibilitas menggunakan rumus Alpha Cronbach, menurut Sudjana (2005:109).

$$
r=\left[\frac{k}{(k-1)}\right]\left[1-\frac{\sum \sigma_{o}^{2}}{\sigma_{,}^{2}}\right]
$$

Keterangan

$\mathrm{r}_{11} \quad$ : Reliabilitas instrumen

$\sum \sigma_{i}{ }^{2}$ : Skor tiap-tiap item

$\mathrm{k} \quad$ : Banyaknya butir soal

$\sigma_{t}{ }^{2} \quad$ : Varians total

\section{HASIL DAN PEMBAHASAN}

Deskripsi data pada penelitian menjabarkan skor hasil belajar IPS yang dipengaruhi oleh faktor strategi pembelajaran sebagai faktor pertama dan gaya berpikir sebagai faktor kedua. Faktor strategi pembelajaran yang digunakan adalah strategi pembelajaran berbasis masalah dan strategi pembelajaran kooperatif. Sedangkan faktor gaya berpikir dibedakan berdasarkan gaya berpikir divergen dan gaya berpikir konvergen.

Rata-rata Hasil Belajar pada setiap Kelompok Perlakuan

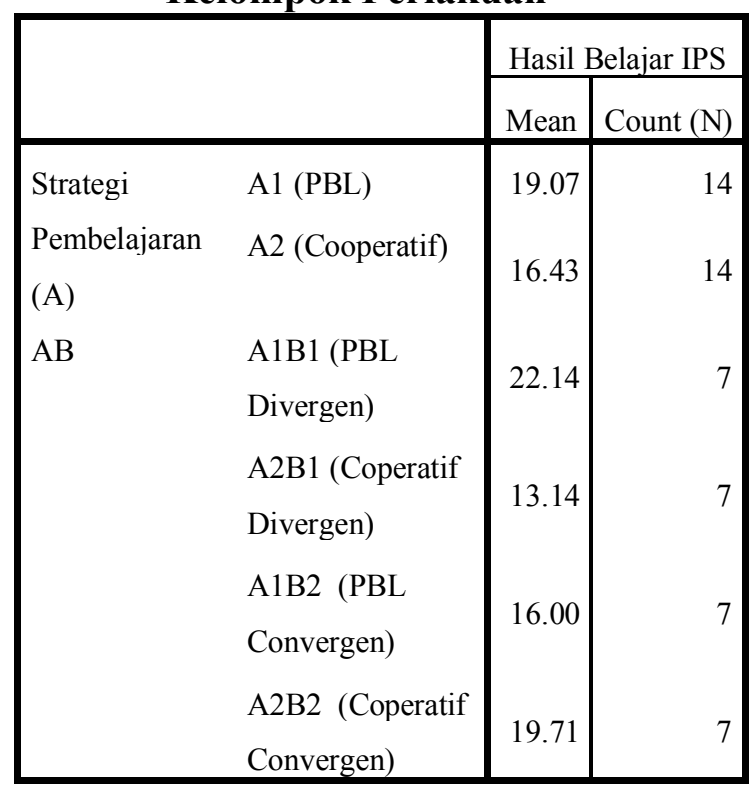

\section{Rangkuman Hasil Perhitungan Analisis Varians (ANAVA) Dua Jalur Tests of Between-Subjects Effects Dependent Variable: Hasil Belajar IPS}

\begin{tabular}{|l|r|r|r|r|r|}
\hline & \multicolumn{1}{|c|}{$\begin{array}{r}\text { Type III } \\
\text { Sum of }\end{array}$} & & \multicolumn{1}{|c|}{ Mean } & & \\
Source & \multicolumn{1}{c|}{ Squares } & df & \multicolumn{1}{c|}{ Square } & \multicolumn{1}{c|}{$\mathrm{F}$} & Sig. \\
\hline Corrected & $332.107^{\mathrm{a}}$ & 3 & 110.702 & 19.373 & .000 \\
Model & 8821.750 & 1 & 8821.750 & 1543.806 & .000 \\
Intercept & 48.893 & 1 & 48.893 & 8.556 & .007 \\
A & .321 & 1 & .321 & .056 & .815 \\
B & 282.893 & 1 & 282.893 & 49.506 & .000 \\
A * B & 137.143 & 24 & 5.714 & & \\
Error & 9291.000 & 28 & & & \\
Total & 469.250 & 27 & & & \\
Corrected & & & & \\
Total & & & & \\
\hline
\end{tabular}

a. R Squared $=.708$ (Adjusted R Squared $=.671$ )

Berdasarkan hasil penelitian dapat dibahas beberapa hal sebagai berikut:

1. Terdapat Perbedaan Hasil Belajar IPS antara Siswa yang Belajar dengan Strategi Pembelajaran Berbasis 
Masalah dan Strategi Pembelajaran Kooperatif (A1 Dan A2).

Dalam penelitian telah ditemukan bahwa terdapat perbedaan yang signifikan hasil belajar IPS antra siswa yang belajar dengan strategi pembelajaran berbasis masalah dengan siswa yang belajar menggunakan strategi pembelajaran kooperatif. Hasil belajar IPS pada siswa yang memilkki strategi pembelajaran berbasis masalah lebih tinggi dibandingkan siswa yang menggunakan strategi pembelajaran kooperatif.

Hal ini karena siswa yang belajar dengan strategi pembelajaran berbasis masalah memberikan kesempata kepada siswa untuk aktif dan kreatif mengembangkan potensi intelektualnya dalam kegiatan yang dikembangkan sendiri.

2. Pengaruh Interaksi Strategi Pembelajaran dan Gaya Berpikir Terhadap Hasil Belajar IPS (A X B)

Besar pengaruh interaksi antara strategi pembelajaran dan Gaya berpikir terhadap hasil belajar IPS adalah 70,8\% (R.Squared $=0,708$ ). Hasil penelitian pada pengujian hipotesis menunjukkan terdapat pengaruh interaksi antara strategi pembelajaran (strategi pembelajaran PBL dan strategi pembelajaran kooperatif) dan memiliki Gaya berpikir terhadap Hasil belajar IPS.

\section{Siswa dengan Gaya Berpikir} Divergen, Memiliki Hasil Belajar IPS Lebih Baik Bila dengan Strategi Pembelajaran Berbasis Masalah

Skor hasil belajar IPS siswa yang belajar dengan strategi pembelajaran berbasis masalah dengan Gaya berpikir divergen (A1B1) adalah 22,143 sedangkan skor rata-rata skor hasil belajar IPS yang belajar dengan strategi pembelajaran Cooperatif dengan Gaya berpikir divergen (A2B1) adalah 13,142 dan Uji Tuckey menunjukkan perbedaan rata-rata skor sebesar 9,00 dan nilai $\mathrm{p}$-value (Sig) sebesar 0,000
$(0,000<0,05)$. Hal ini menunjukkan terdapat perbedaan yang signifikan hasil belajar IPS siswa yang belajar dengan strategi pembelajaran berbasis masalah dan strategi pembelajaran kooperatif pada siswa dengan gaya berpikir divergen.

4. Siswa dengan Gaya Berpikir Konvergen, Hasil Belajar IPS Lebih Baik Pada Siswa yang Menggunakan Strategi Pembelajaran Kooperatif (A1B2 Dan A2B2)

Skor rata-rata hasil belajar IPS yang belajar dengan strategi pembelajaran berbasis masalah dengan Gaya berpikir convergen (A1B2) adalah 16,00 sedangkan skor rata-rata hasil belajar IPS yang belajar dengan strategi pembelajaran kooperatif dengan Gaya berpikir convergen (A2B2) adalah 19,71 dan Uji Tuckey menunjukkan perbedaan rata-rata skor sebesar 3,00 dan nilai p-value (Sig) sebesar 0,036 $(0,036<0,05)$. Hal ini menunjukkan terdapat perbedaan signifikan hasil belajar IPS siswa yang belajar dengan strategi pembelajaran berbasis masalah dan strategi pembelajaran kooperatif pada siswa dengan gaya berpikir convergen.

\section{KESIMPULAN}

Berdasarkan uraian diatas, terbukti bahwa penggunaan strategi pembelajaran sebaiknya disesuaikan dengan gaya berpikir siswa. Pada kasus penelitian ini penggunaan dan penerapan strategi pembelajaran berbasis masalah lebih baik digunakan untuk siswa yang memiliki gaya berpikir divergen, sementara penggunaan dan penerapan strategi pembelajaran kooperatif lebih baik digunakan untuk siswa yang berpikir konvergen. Oleh karena itu bagi siswa yang memiliki gaya berpikir divergen, dapat ditingkatkan hasil belajarnya melalui strategi pembelajaran berbasis masalah, sedangkan untuk siswa yang memiliki gaya berpikir konvergen dapat 
ditingkatkan hasil belajarnya melalui strategi pembelajaran kooperatif.

\section{Implikasi}

Dari hasil temuan di lapangan dan hasil pengujian hipotesis dapat memberikan berbagai macam implikasi penelitian sebagai berikut :

1. Hasil penelitian ini menunjukkan bahwa hasil belajar IPS siswa yang diajarkan menggunakan strategi pembalajaran berbasis masalah lebih tinggi dibandingkan dengan siswa yang diajarkan dengan menggunaka pembelajaran kooperatif.

2. Untuk mencapai hasil belajar IPS siswa dengan maksimal, maka diperlukan guru yang mempunyai kemammpuan memilih strategi pembelajaran dengan tepat yang sesuai dengan gaya berpikir yang dimiliki siswa, menguasai materi pembelajaran dengan baik, memahami serta dapat membantu menyelesaikan permasalahan yang dialami siswa, bisa membangkitkan motivasi siswa untuk belajar IPS.

3. Berdasarkan hasil penelitian menunjukkan bahwa hasil belajar IPS yang dibelajarkan dengan menggunakan strategi pembelajaran berbasis masalah lebih tinggi dibandingkan dengan hasil belajar IPS siswa yang dibelajarkan dengan strategi pembelajaran kooperatif. Hal ini berpengaruh terhadap pergeseran paradigma sistem pembelajaran IPS.

4. Hasil penelitian ini menunjukkan bahwa gaya berpikir yang dimiliki peserta sangat mempengaruhi hasil belajar IPS. Siswa yang memiliki gaya berpikir divergen yang dibelajarkan menggunakan strategi pembelajaran berbasis masalah hasil belajar yang dicapai lebih tinggi diabndingkan dengan siswa yang memiliki gaya berpikir divergen yang dibelajarkan dengan strategi pembelajaran kooperatif. Sedangkan siswa yang memiliki gaya berpikir konvergen memiliki hasil belajar yang lebih tinggi bila dibelajarkan dengan menggunakan strategi pembelajaran kooperatif dibandingkan dengan strategi pembelajaran berbasis masalah.

5. Unit penelitian dan pengembangan sebagai lembaga yang memiliki tugas mengembangkan kompetensi guru serta mengevaluasi kesiapan bahan ajar dan strategi pembelajaran,

\section{Saran}

Berdasarkan kesimpulan dan implikasi penelitian yang telah diuraikan di atas, maka Saran yang dapat disampaikan sebagai rekomendasi bagi stakeholders adalah:

1. Guru harusnya menggunakan pendekatan berbasis masalah selain menggunakan pembelajarn kooperatif.

2. Guru dapat mempertimbangkan perbedaan karateristik siswa, misalnya gaya berpikir (divergen dan konvergen), hal ini penting dilakukan agar dalam proses pembelajaran, guru memahami kebutuhan siswanya.

3. Berdasarkan temuan penelitian yang sudah dibahas sebelumnya, strategi pembelajaran berbasis masalah mengakomodasi gaya berpikir divergen dan konvergen. Hal ini menunjukkan bahwa strategi pembelajaran berbasis masalah tepat digunakan untuk siswa yang memiliki gaya berpikir divergen maupun konvergen.

4. Penelitian tersebut tidak terlepas dari berbagai keterbatasan dan kekurangan. Oleh karena itu untuk dapat memperoleh data empiric dan oengetahuan yang lebih luas, maka dperlukan penelitian lanjutan dengan memperhatikan variabel-variabel lain, misalnya: (1) variabel perbedaan karakteristik individu; (2) jenis tes hasil belajar yang relevan dengan karakteristik siswa. Hal ini sangat penting untuk dilakukan dalam rangka meningkatkan kemampuan siswa dan emngoptimalisasikan proses belajar mengajar. 


\section{REFERENSI}

Aisyah, Siti. 2012. Pengaruh Strategi Pembelajaran dan Gaya Berpikir Terhadap Hasil Belajar Bahasa Indonesia Http://jurnal. unimed.ac.id/ 2012/index. $\mathrm{php} / \mathrm{jtp} /$ article/ view/ 3320/ 2987 (diakses 25 Januari 2019)

Anastasia, Anne. Psychological Testing 7th edition. terjemahan Susana. 1997. Jakarta : PT indeks.

Anderson, L.W. \& Krathwohl, D.R. Kerangka Landasan Pembelajaran, Pengajaran, dan Asesmen: Revisi Taksonomi Bloom. 2015. Yogyakarta: Pustaka Pelajar.

Arikunto, Suharsimi. Dasar-dasar Evaluasi Pendidikan (Edisi Revisi). 2009. Jakarta: Bumi Aksara.

Arends, Ricards. Learning To Teach, Ninth Edition. 2012. New York: McgrawHill Companies.

Banks \& Ambrose. Teaching Strategies for the Social Studies. 1990. New York: Longman.

Bloom, Benjamin S., et al. Taxonomy of Education Objectives, Handbook I: Cognitive Domain. 1979. London : Longman Group LTD.

Briggs, Leslie J. Instructional Design:Principles and Application. 1979. New Jersey:Prentice Hall,Inc.

Cohen, Ronald Jay., Swerdlik, Mark E. Psychological Testing and Assessment An Introduction to Test and Measurement (9 Edition). 2018. New York :McGraw-Hill Education.

Creswell, J. W. Research Design : Qualitative, Quantitative, and Mixed Methods Approaches. 2009. Los Angeles: Sage.
Djaali., Mujiono, dan Pudji. Pengukuran Dalam Bidang Pendidikan. 2008. Jakarta: Grasindo.

Delisle, Robert. How to Use ProblemBased Learning in the Classroom. 1997. Virginia:ASCD.

Dick, Walter. The Systematic Design of Instruction. 2015. USA:Pearson Educational Inc.

Eggen, P. \& Kauchak, D. Strategi dan Model Pembelajaran Mengejar Konten dan Keterampilan Berfikir. 2012. Jakarta: Indeks.

Elliott, Stephen E., et. Al. Educational Psychology : Effective Teaching, Effective Learning 3th Edition. 2000. New York:Mc Graw Hill Companies, Inc.

Fathurrohman, Muhammad. Model-model Pembelajaran Inovatif. 2015. Yogjakarta :Ar Ruzz Media.

Gagne, Robert M. The Conditions Of Learning (3th edition). 1977. New York :Rinehart and Winston.

Gagne, Robert M. 2005. Principles of Instructional Design United State of America: Wadsworth Thomson Learning.

Gay, L.R. and Mills. Airasian. Educational Research: Competencies for Analysis and Application, Tenth Edition. 2012. New Jersey:Pearson Education Inc.

Gunadi, R. Andi Ahmad. 2014. Pengaruh Strategi Pembelajaran dan Konsep Diri Terhadap Hasil Belajar Mata Kuliah Ilmu Pendidikan. Jurnal Ilmiah Widya. Volume 2 No.3.

Guilford, Joy Paul. Structur of Intellect Model,http://instructionaldesign.org/theori es/intelect.htnl. (diakses 25 Januari 2019) 
Iskander, Magued. Innovative Techniques in Instruction Technology, E learning, E assessment and Education. 2008. Newyork : Springer.

Kadir. Statistika Terapan: Konsep, Contoh, dan Analisis Data dengan Program SPSS/Lisrel dalam Penelitian. 2015. Jakarta : Rajawali Pers.

Kafadar, Hatice. Cognitive Model of Problem Solving. 2014. Turkey : Department of Psychology Division of Experimental Psycology.

Kincaid, Harold. Philosophical Foundations of the Social Sciences: Analyzing Controversies in Social Research. 1996. England : Cambridge University Press.

Kuswana, Wowo S. Taksonomi Berpikir 2011. Bandung : Remaja Rosda Karya.

Kolb, David.A. Experiential Learning: Experience as the Source of Learning and Development. 2014. New Jersey: Pearson.

Lubis, Asri.Instrumen Penelitian Pendidikan.http://www.digilib.unimed.ac.i d/203/ (diakses 7 November 2018).

Mausner, Bernard. A Citizen's Guide to the Social Science. 1979. Chicago:NelsonHall.

Purwanto, M. Ngalim. Prinsip-prinsip dan Teknik Evaluasi Pengajaran. 2002. Bandung: P.T. Remaja Rosdakarya.

Purwowidodo, Agus. 2016. Pengaruh Strategi Pembelajaran Dan Gaya Berpikir Terhadap Pemahaman Dan Penerapan Konsep IPS Siswa Kelas VII SMP. Jurnal Ilmu pendidikan, Jilid 22 No.2.

Richey, Rita C., Klein, James D., Tracey, Monica W. The Instructional Design Knowledge Base:Theory, Reaserch, and Practice. 2011. New York:Routledge.
Sappaile, Baso Intang. Validitas dan Reliabilitas Tes yang Memuat Butir Dikotomi dan Politomi. http://www.eprints.unm.ac.id/7677/1/ART IKEL\%20TESIS.docx.(diakses 7 November 2018)

Sanjaya, Wina. Penelitian Pendidikan Jenis, Metode dan Prosedur. 2013. Jakarta:Kencana Prenada Media Group.

Santrock, John W. Educational Psycology (3th Edition), terjemahan Angelica D. 2009. Jakarta : Salemba Humanika.

Saracho, Olivia N. Teachers and Students Style in Erarly Childhood Education.1997. Westport: Bergin \& Garvey.

Slavin. Robert E. Educational Psychology, Theory and Practice (9th edition) Terjemahan Samosir M. 2011. Jakarta: PT. Indeks.

Smaldino, Sharon E. Instructional Media and Technologies for Learning (7th Edition). 2001. Merris Prentice Hall: Ohio.

Seng Tan, Oon. Problem-based Learning Innovation: Using problems to power learning in the 21st century. 2009. Singapore: Cengage Learning Asia Pte Ltd.

Sudiyono, A. Pengantar Evaluasi Pendidikan. 1996. Jakarta: PT Raja Grafindo Persada.

Sudjana, N. Penilaian Hasil Proses Belajar Mengajar. 2006. Bandung: PT. Remaja Rosdakarya.

Sugiyono. Metode Penelitian Pendidikan (Pendekatan Kuantitati, Kualitatif, dan R\&D).2011. Bandung: Alfabet.

Somantri, Nu'man. Menggagas Pembaharuan Pendidikan IPS. 2001. PT. Remadja Rosda Karya. 
Spector, Michael J. Foundation of Educational Technology: Integrative Approaches and Interdisciplinary Perspective. 2012. New York: Routledge.

Solso,Rober L. M. McLin, Kimberly., and McLin,,Otto H. Cognitive Psychology (7th edition). 2005. New York: Pearson Educatin Inc.

Weisberg, Robert W. Creativity:Understanding Innovation in Problem Solving, Science. Invention and The Art. 2006. New Jersey:John Wiley \& Sons.

Wicaksono, Dirgantara. Buku Panduan Guru Strategi Pembelajaran Berbasis Masalah. 2015. Jakarta. Edukasi Gemilang.

Woolfolk, Anita. Educational Psychology. 2016. England:Pearson Education Inc. 